\title{
The Future of Nigeria's National Youth Service Corps Programme: Any Hope for National Integration?
}

\author{
Leke Abraham OLUWALOGBON \\ Department of Political Science and Public Administration \\ Redeemer's University, Ede, Osun State, Nigeria \\ E-mail: oluwalogbonl@run.edu.ng
}

Received: Feb. 3, 2019 Accepted: Feb. 28, 2019 Online published: Apr. 17, 2019

doi:10.5296/jpag.v9i2.14312ＵRL: https://doi.org/10.5296/jpag.v9i2.14312

\begin{abstract}
The National Youth Service Corps was established under Decree 24 of 1973 to foster national unity. It was one of the post-civil war strategies of reconciling the warring groups and building a united Nigeria. At its inception, the programme was generally well received, however as time progressed, some destabilizing factors began to dim the hope of its continuity. This study therefore aims at investigating to what extent the National Youth Service Corps programme will remain a viable instrument of national integration in the coming years. Using the quantitative research orientation, 400 copies of a questionnaire were administered among current participants, former participants, prospective participants as well as non-participants across four (4) Local Government Areas in Lagos and Ogun States. A total of 345 completed questionnaires were returned, giving a rate of return of $86.25 \%$. The analysis of the data was essentially by descriptive statistical methods including, frequency tables and simple percentile. The result suggests that the National Youth Service Corp programme is currently being threatened by the twin challenges of insecurity and youth unemployment. $49.4 \%$ of respondents opined that they influenced their postings due to security issues, while $29.3 \%$ influenced theirs based on job placement. $63.7 \%$ confirmed that there will no need of influencing their postings if the challenges of security and unemployment were resolved. The study therefore recommends that government at all levels do the needful to mitigate these challenges, if the dream of a united Nigeria will be realized.
\end{abstract}

Keywords: national youth service corps, national integration, security, youth unemployment

\section{Introduction}

The National Youth Service Corps (NYSC) programme was one of the post-civil war integration strategies adopted by the General Yakubu Gowon - led military administration, which aimed at burying the acrimonies that sparked off the war, as well as forge ahead as a 
united nation. Its establishment was greeted with great expectations as national unity was then the single most important agenda. However, there has been mixed reactions about the relevance and the continuity of the programme over the years. There are conflicting opinions about the programme, with some calling for its outright scrapping. Some of the problematic issues enumerated include; the lack of financial efficiency, that is, the financial input far outweighs the output. It is also a widely held belief that the youth, who are the target group, are inappropriate because their perceptions are already formed and as such cannot be easily persuaded or dissuaded from their strongly held beliefs. There is also the view that the programme is a source of cheap labour, offering corps members' paltry stipends that is never commensurate with the services rendered (Egunyomi, 2017).

In the wake of the numerous political, ethnic and religious conflicts that have engulfed Nigeria and claimed the lives of innocent corps members, the continuity of the programme is being further threatened, particularly because parents are now wary of releasing their children to serve in distant places outside their home states particularly in the North. The call for the regionalization of the programme or its outright abolition has cast aspersion on its continuity and its relevance in Nigeria's present circumstances as an instrument of national integration (Odumade, 2016). Furthermore, there are some internal contradictions within the NYSC itself that have made the objectives of national integration elusive. One of such contradictions is the policy on posting, which according to the NYSC decree, corps members ought to be posted to states other than their states of origin. Present realities have shown however that a number of corps members do not move out of their states of origin, and a few that do, don't move out of their ethnic bases. Another trend noticeable now is that in exchange of monetary rewards, officials assign corps members to states of their choice. This act of favoritism in postings is a direct confrontation to the objective of national integration.

The level of corruption within the NYSC itself, which today has reached an unprecedented height, has made the youths disgruntled, thus making the programme counter-productive (Ojo 2009:76). The paltry stipend which corps members receive is demoralizing, and has led many corps members to abandon their duty posts in order to augment their earnings. Indeed, it appears the relevance of the programme has been questioned due to these negative developments. Hurting, maiming and killing of corps members, together with the internal contradictions have combined to throw up a huge debate among the protagonists and antagonists of the programme. This study has assumed great importance because national integration, particularly in plural societies, is a prerequisite for development as well as democratization. Hence, its absence in a democratic state like Nigeria will not only stall development, but also hinder the process of democratization. Ultimately it could lead to anarchy. This paper therefore seeks to provide answers to the following questions; (i) will the programme remain a relevant strategy for national integration in Nigeria in the nearest future? (ii) what can be done to make the programme serve its desired purpose(s)? The paper is organized into eight (8). Following this introductory section, are sections on the concept of National Integration, the National Youth Service Corps as an integrative mechanism, the objectives of the National Youth Service Corps, Methodology, Analysis of Data, Conclusion and then Policy recommendations. 


\section{National Integration: A Conceptualization}

National integration is the process of unifying a multi-ethnic country, not necessarily into a single-ethnic one but into a united indivisible entity where primordial affiliations are made secondary for the greater good of the united nation. It can also be seen as the building of a national state but of disparate social, economic, religious, ethnic and geographical elements which entails the translation of diffused and unorganized sentiments on nationalism into a spirit of citizenship through the creation of state institutions that can translate into policies and programmes and aspirations of the citizenry (Oni and Ogundinwin, 2010).

In their own submission, Fatile and Adejuwon (2010) conceptualize national integration as the process whereby several disparate groups within a given territorial entity are united together or co-operate under conditions which do not appear to permit satisfaction of the system needs in any other way. They concluded by stating that the goal of national integration is an arrangement in a plural society where component parts are reasonably contented in the polity vis-a-vis equity and justice in resource allocation and access to equal opportunities. It must also be stated that it is the progressive reduction of cultural and regional tensions and discontinuities in the process of creating a homogenous political community (Coleman and Rosberg, 1964 in Amienyi, 2005).

Duverger (1976) in Ojo, (2009) defines it as the process of unifying a society which tends to make it a harmonious city based upon an order its members regard as equitably harmonious. To Haas (cited in Ayoade 1998:110) national integration is a process whereby political actors in distinct national settings are persuaded to shift their loyalties, expectations and political activities towards a new centre, whose institutions possess or demand jurisdiction over the pre-existing nation-state. Also, Ogunojemite (1987) (cited in Agbodike, 1998:183) defines national integration as a process leading to political cohesion and sentiments of loyalty toward a central political authority and institutions by individual belonging to different social groups or political unit.

Morrison and Stevenson (1971: 903) define it as the degree of cohesion that binds members of social systems together, and is generally thought of in terms of the values, institutions and communications which facilitate escalating sequences of social contact, cooperation and consensus. They further identify four dimensions of national integration namely: horizontal integration, vertical integration, value integration and centralization. They describe horizontal integration as the degree to which members of a national political system have facilities for communication and transactions with other members who hold similar roles in the stratification system. They established the link between communications and integration on the assumption that a positive correlation exists between the extent of interaction between two people and their mutual liking and co-operation. They measured horizontal integration by the extent to which facilities for communication or communications potential are developed within nations.

Vertical integration, according to them, is the degree to which political actors in different strata are linked together usually called the mass-elite gap. The argument here is that disintegration is looming if the elite is unable to rapidly communicate its commands and 
decisions to the mass and swiftly respond to their demands. They identify values and identity incongruities as the causes of inadequate communication between the two populations. Therefore, to achieve national integration, the core values of the elites should be inculcated in the minds of the mass public. They measured the mass-elite gap by finding the difference between the proportional representation of ethnic groups in the elite and the proportion of these groups in the total population. Value integration is what they described as the degree of value congruence in a society. By this, they mean to a certain extent values should be commonly shared among the people, agreeing that it is difficult to identify the range of common values that should be shared, they however listed two; the first is the common values relating to the definition of political community and to its membership and secondly, common values relating to the structure of authority and the legitimization of the exercise of power. Achieving value integration is particularly hindered by the pluralistic nature of many countries. They measure this in terms of language and religious heterogeneity in nations, and by the cultural differences between ethnic units.

Lastly, centralization is the extent to which the individuals in a political system are subject to the decisions of a central authority, having the capacity to mobilize coercion to enforce compliance with its decisions. This they measured in terms of the homogeneity of the party and legislative organizations and in terms of the increasing economic role of government in spending and taxing. It was also measured by the growth of military and security systems and by the coercive restrictions imposed by government on people and organizations. As it could have been observed from the definitions given above, the concept under review is a complex one. It consists not only of the socio-cultural, economic and political dimensions, but also of cognitive attitudinal and behavioral dimensions (Amienyi 2005:4).

\section{The National Youth Service Corps Programme as an Integrative Mechanism}

The National Youth Service Corps was established under Decree 24 of 1973, and was promulgated on 22 May 1973. A total of 2,117 youths participated in its first year. The programme was arrived at to foster unity in the face of ethnic diversity following the unsuccessful attempt of the Eastern Region to secede, which resulted in the 30-month civil war (1967-70). It was urgent upon the Federal Military Government (FMG) to secure the victory over the failed Biafran nation, by setting in motion, an instrument that will ensure a peaceful co-existence not only with the Eastern Region, but also among all ethnic groups across the regions. Indeed, the immediate challenge of the post- war period was how to 'engage in deliberate social engineering, designing programmes and pursuing policies meant to promote national unity, de-emphasize points of discord among constituent groups, and foster greater inter-ethnic understanding and harmony' (Enegwea and Umoden, 1993 cited in Obadare 2010:22).

The choice of the youth for the programme above every other age group was based on the fact that they are considered as change agents needed for building a united Nigeria, and a way of achieving this is for the youths to imbibe and nurture a sense of common belonging and national consciousness which would transcend political, social, state and ethnic loyalties. The choice of the youth for the programme also stemmed from two continent - wide problems 
namely: youth unemployment and the emigration of young unskilled people from rural areas to urban ones. It was also a way for the nation to invest in its future; since youths constitute a dominant force for national mobilization and growth (Obadare, 2007:40).

Ojo (2009), arguing on the side of policy makers, who were of the opinion that an interaction among the emergent elite especially outside their ethnic base would enhance a better understanding among the various ethnic groups, justified the establishment of the National Youth Service Corps programme. To be sure, the enabling legislation that established the NYSC, Decree 24 of 1973 states explicitly the objectives as well as modus operandi of the programme. Of great significance to the concept of national integration is the objective of developing common ties among the various youths and to promote national unity by ensuring that the youths are assigned to jobs in states other than their states of origin, with the intent of removing prejudices and eliminating ignorance among the young graduates- the emerging elite.

Though a lofty goal, its attainment has been mostly elusive. The success of the programme is limited to the making of the friends, the displacement of old prejudices and very significantly, inter-cultural marriages during the service year. However, he hinged the failure of the programme not achieving its national integration objective to the fullest, to the poor implementation of the programme, which is visible in the act of favoritism in postings. The height of brazen corruption has also stunted the programme in that the youth themselves are disgruntled and disillusioned, thereby making the programme counterproductive. The disproportionate relations between the stipend paid and the service rendered on the one hand, and on the other hand, the ever-increasing inflation rate. The programme ceases to be a service programme, rather it has become, as some youths have tagged it a suffering programme. The failure of the programme is also seen in the eagerness of participants to return to their home states after each service year, this trend he ascribes to the problematic nature of citizenship in Nigeria, whereby a non- indigene is not accorded the same rights and privileges as an indigene. His conclusion thus follows that rather than being an integrative mechanism, the NYSC has become a nightmare of some sort, with calls for its rejuvenation and even its abolition.

In a survey carried out on the NYSC as an attempt to foster national unity in the face of ethnic diversity, Iyizoba (1982) attempts to evaluate the success of the youth corps programme in achieving the goal of reducing inter-ethnic prejudice amongst the various ethnic groups in Nigeria. Adopting a cross-sectional strategy and using a sample size of 75 current and past participants of the programme, he discovered that exposure to other ethnic groups were significantly related to prejudice of respondents; in other words, those that have had some exposure to other ethnic groups were significantly less prejudiced than those with no exposure. This result gives the programme a positive score. The policy adopted to post youths to states other than their states of origin has eventually been justified as a right step in the right direction.

However, has Iyizoba (1982: ii) also states, the timing of the inter-ethnic contact also matters. The contact that occur among the participants is rather too late to bring about the expected 
change in the youths. At the youth stage, it is believed that the attitudes are already formed and thus change becomes difficult. Sundry other challenges militate against the programme such as administrative incompetence on the part of the senior administrators of the programme who lack the administrative skills and the professional orientation morally required of programme like this. The resentment about coercive elements in the programme, such as its mandatory nature, forced military training, and inappropriate monetary compensation.

In another study, Obadare (2010) examines the service - citizenship link. The study particularly answers the questions on how the relationship between civic service and citizenship is to be understood, and how service affects citizenship. While the predominant assumption in the extant literature of service is that it is antecedent to, and necessarily impacts positively on citizenship, the study reached a contrary conclusion, that the conception of and the prior allegiance to a community is essential for the creation and nurturing of actual citizenship, and national service. Data for this study was drawn from a combination of open ended interviews, a questionnaire survey and focus group discussions. Respondents for the study were drawn from both serving and former participants of the NYSC programme.

\section{Objectives of the Programme}

Section 1 (3) of the Decree 24 of 1973, later amended as Decree 51 of 1993 that established the National Youth Service Corps stated the objectives of the programme as follows:

(a) To inculcate discipline in Nigerian youth by instilling in them a tradition of industry at work and of patriotic and loyal service to Nigerian any situation they may find themselves;

(b) To raise the moral tone of the Nigerian youths by giving them the opportunity to learn about higher ideals of nation achievements, social and cultural improvement;

(c) To develop in Nigerian youths the attitude of mind, acquired through self-experience and suitable training, which will make them more amenable to mobilization in the national interest;

(d) To enable Nigerian youths, acquire the spirit of self-reliance by encouraging them to develop skills for self-employment;

(e) To contribute to the accelerated growth of national economy;

(f) To develop common ties among the Nigerian youths and promote national unity and integration;

(g) To remove prejudices, eliminate ignorance and confirm at first hand the many similarities among Nigerians of all ethnic groups; and

(h) To develop a sense of corporate existence and common destiny of the people of Nigeria.

In order to achieve the objectives as stated above, the Decree further stated how the 
objectives will be achieved. The service corps shall ensure:

(a) the equitable distribution of member of the service corps and the effective utilization of their skills in area of national needs;

(b) that are far as possible, youths are assigned to jobs in states other than their states of origin;

(c) that such groups of youths assigned to work together is as representative of Nigeria as far as possible;

(d) that the Nigerian youths are exposed to the mode of living of the people in different parts of Nigeria;

(e) the Nigerian youths are encouraged to eschew religious intolerance by accommodating religious differences;

(f) the members of the service corps are encouraged to seek a year for their one - year national service, career employments are over Nigeria, thus promoting the free movement of labour;

(g) that employers are induced partly though their experience with members of the service corps to employ more readily and on a permanent basis, qualified Nigerians, irrespective of the state or origin.

While it is true that from the stated objectives of the programme, its main focus is national unity and integration. However, it seems that, that has become a secondary objective, seeing that the programme has become a ready source of cheap educated manpower. As Marenin (1979:634) argues, participants were used, for instance, to run the Universal Primary Education (UPE) programme which the government had embark upon in 1976; apparently the UPE programme was understaffed, thereby necessitating drawing from the NYSC pool to make the programme operational (Moskos, 1988 cited in Obadare 2007: 40). Even till date a large percentage of the corps members are deployed to the teaching profession to make up for the short fall in the number of teachers.

\section{Methodology}

\section{Research Design}

The quantitative research design is adopted for this study. This design enables the researcher to secure a large sample size and a great number of response rates. This design is also capable of explaining the relationships that exist between variables.

\section{The Study Area}

The Southwest region of Nigeria was selected as the study area, using Lagos and Ogun states. The choice of the selected states is based on the following criteria; Lagos stands out among all other states in the region, being the former capital city and at present the economic capital of Nigeria. It is also a metropolitan state and houses several tertiary educational institutions. It was created in 1967, thereby belonging to the first generation of states in the region. Ogun 
state on the other hand, belongs to the third generation of states in the region; it was created in 1976 out of the old western state. It has a good mix of the rural and urban population, and boasts of nine registered universities, the highest in any state in Nigeria. Two Local Government Areas (LGAs) were targeted for this study in each of the two states. Lagos Island and Ikeja LGAs in Lagos state, while Obafemi - Owode and Abeokuta South LGAs were selected in Ogun state. The choice of these LGAs is based on the number of corps members that carry out their national service programme there. These LGAs also serve as the economic nerve centres of the selected states.

\section{Population of the Study}

The population of the study comprises: ex - participants and present participants of the NYSC programme as well as university undergraduates, who are prospective participants of the programme and non- participants also.

\section{Sample Size and Sampling Technique}

The sample size of 400 respondents was purposively selected.

\section{Research Instrument}

A structured questionnaire was adopted. The questionnaire consists of two sections. Section A was designed to capture information on the socio-demographic factors of the respondents, while section B concerned the task of the study. The structured questionnaire used in the cross-sectional survey contained 18 questions. It was distributed equally among the states and local governments. That is, 200 copies each were administered in Lagos and Ogun states. These were equally administered among the four local government areas.

\section{Instrument Return Rate}

The researcher distributed a total of 400 copies of the questionnaires to all the respondents, 345 copies $(86.25 \%)$ were returned.

\section{Data Analysis Techniques}

The analysis of the data was essentially by descriptive statistical methods including, frequency tables and simple percentile.

\section{Analysis of Data}

This section will begin with analyzing data gathered from questions that cut across all the segments of our research population. This is intended to gauge the opinion of respondents, thereby painting the picture of the past, present and the future of the programme. Afterwards, data gathered from the questionnaire administered to each segment of the population will be individually analyzed. 
Table 1. Frequency Distribution of Responses on the Reasons for the Establishment of NYSC

\begin{tabular}{|l|l|l|l|l|l|l|l|}
\hline & NI & JR & NO & CE & CS & OTHERS & TOTAL \\
\hline CURRENT PARTICIPANTS & 32 & 3 & 17 & 9 & 11 & 2 & 74 \\
\hline NON-PARTICIPANTS & 43 & 12 & 18 & 12 & 4 & - & 89 \\
\hline PROSPECTIVE PARTICIPANTS & 35 & 11 & 19 & 14 & 20 & 1 & 100 \\
\hline TOTAL & 110 & 26 & 54 & 35 & 35 & 3 & 263 \\
\hline
\end{tabular}

N.I - National Integration, J.R - Job Requirement, N.O - National Obligation, C.E - Cultural Exchange, C.S - Community Service.

On the overall performance of the programme, $59(22.8 \%)$ of the respondents admitted that the programme has succeeded in achieving its objective. $135(50.8 \%)$ rated the success of the programme has partial, $53(19.9 \%)$ said the programme has not been successful at all, while $19(7.1 \%)$ were indifferent on the matter. In a similar study by Obadare (2010:53-54),14.4\% of the respondents said the programme has been successful, $64.4 \%$ adjudged it as partially successful, $18.9 \%$ as not successful, and $2.2 \%$ were undecided. A careful look at both studies shows that not much has changed. A greater number of the people evaluated the programme as a partial success. With evidences drawn from both studies, the score sheet of the NYSC can be said to be average.

Table 2. Frequency Distribution of Responses on the views of Respondents on National Service outside their Ethnic Bases

\begin{tabular}{l|l|l|l}
\hline & YES & NO & TOTAL \\
\hline CURRENT PARTICIPANTS & 4 & 68 & 72 \\
\hline EX PARTICIPANTS & 72 & 17 & 89 \\
\hline NON-PARTICIPANTS & 53 & 33 & 86 \\
\hline PROSPECTIVE PARTICIPANTS & 54 & 43 & 97 \\
\hline TOTAL & 183 & 161 & 344 \\
\hline
\end{tabular}

The official stand of the NYSC on posting is that all postings should be outside the participant's state of origin, except on marital and health grounds (Ojo, 2009:76). However, it has been observed that the legal provision as stated in Section 1(4) (b) of the enabling law is not far reaching, and seems to be hypocritical. Some officials of the programme have also taken advantage of such a loop hole, by manoeuvring the system to post participants outside their states of origin, but within their ethnic base. Thus, a participant, who hails from Imo state for instance, will be posted outside Imo, but within the South Eastern geo-political zone. This trend is fast gaining ground and is systematically eroding the core objective of the programme. But for the successive state creation exercises, states as they stand today were 
units under the old regions, namely the Northern, Eastern, and Western. Thus, states within each geo-political zone are homogeneous, culturally and in terms of language.

Table 2 therefore sought to examine the extent to which participants actually serve outside of their ethnic bases. Of the 72 current participants that responded, only 4 (5.6\%) were serving outside their ethnic bases, the remaining 68 (94.4\%) were within their ethnic bases. 72 $(80.9 \%)$ of ex- participants noted that they served outside their ethnic bases, $17(19.1 \%)$ others served within their ethnic bases. The prospective participants were asked if they would like to serve outside their ethnic bases. $54(55.7 \%)$ responded in the affirmative, while $43(44.3 \%)$ negated the idea of serving outside their ethnic base. Of the 86 non-participants that were asked if they would allow their wards or children serve outside their ethnic bases, 53(61.6\%) would accept their wards or children to serve outside their ethnic base, while 33(38.4\%) were averse to the idea of allowing their wards serve outside their ethnic base. Observing from the responses of the current and ex-participants, there seem to be a downward slide in the number of participants that serve outside their ethnic bases. This might not be unconnected with the series of hazards that corps members have been exposed to in the course of their service. Available data show that in the year 2011 alone; about 50 corps members lost their lives in the various civil disturbances and unrest, while many others have suffered from premeditated violence such as rape (Adenle, 2009).

Table 3. Frequency Distribution of Responses on Respondents' Preferred Zone or Region of Service

\begin{tabular}{l|l|l|l|l|l|l|l}
\hline & SE & SS & SW & NC & NE & NW & TOTAL \\
\hline NON-PARTICIPANTS & 20 & 17 & 52 & 3 & - & 3 & 95 \\
\hline $\begin{array}{l}\text { PROSPECTIVE } \\
\text { PARTICIPANTS }\end{array}$ & 11 & 19 & 59 & 4 & 1 & 1 & 95 \\
\hline TOTAL & 31 & 36 & 111 & 7 & 1 & 4 & 190 \\
\hline
\end{tabular}

SE-SOUTH EAST, SW-SOUTH WEST, SS-SOUTH SOUTH, NC-NORTH CENTRAL, NENORTH EAST NW-NORTH WEST

As a follow up to the preceding table, Table 3 seeks to further establish how consistent respondents are to the issue of national service outside of their ethnic bases. With particular interest to the two groups of respondents that do not have direct contact with the programme, the researcher seeks to know, the preferred zone or region of service the prospective and non-participants will choose if given the opportunity to determine where to serve. Of the 190 respondents, 31(16.3\%) prefer the South East, 36 (18.9\%), the South South, and $111(58.4 \%)$ chose the South West. $7(3.7 \%)$ respondents chose to serve in the North Central. $1(0.5 \%)$ respondent chose to serve in North East and 4(2.1\%) in the North West zone. As it can be seen, more respondents chose the South West, specifically, 52(54.7\%) of non-participants, and $59(62.1 \%)$ of prospective participants. This situation is worrisome and should put policy makers on their toes. While it is true that participants ought to serve outside their states of origin, there exists an obvious unwillingness on the part of respondents to leave their ethnic 
bases or allow their wards or children do so.

Table 4. Frequency Distribution of Responses on the Disposition of Respondents to the act of Influencing Postings to States of Service

\begin{tabular}{l|l|l|l|l}
\hline & YES & NO & INDFFERENT & TOTAL \\
\hline $\begin{array}{l}\text { CURRENT } \\
\text { PARTICIPANTS }\end{array}$ & 39 & 28 & 3 & 70 \\
\hline EX PARTICIPANTS & 17 & 69 & 4 & 90 \\
\hline NON-PARTICIPANTS & 37 & 46 & 8 & 91 \\
\hline $\begin{array}{l}\text { PROSPECTIVE } \\
\text { PARTICIPANTS }\end{array}$ & 63 & 17 & 14 & 94 \\
\hline TOTAL & 156 & 160 & 29 & 345 \\
\hline
\end{tabular}

Having established with the views of the non-participants and prospective participants in Table 3, that a great number of respondents prefer to serve within their ethnic bases than to explore other regions. It is important to further establish what has been stated above. This will be done in the light of what Ojo (2009:76) notes;

... the programme is bedeviled with the specter of favouritism in postings. It is an open secret that a large chunk of corps members do not move away from their ethnic bases if they move away from their states of origin at all, whereas, except on marital and ill- health grounds, corps members are supposed to be posted away from their natural habitats.

Could it be that the programme has been compromised in terms of the posting of participants? Table 3, seeks to empirically authenticate the claim of favouritism in the posting process. Of the 70 current participants who responded, 39 (55.7\%) accepted that they influenced their posting to their current state of service, 28(40\%) declined that they influenced posting and $3(4.3 \%)$ were indifferent to the matter.

There are two likely possibilities; the first is the possibility of favoritism as stated by Ojo (2009), which has allowed participants to influence their postings. The second could be the obnoxious provision on posting that allows the participant to be posted to any state as long as it is not the participant's state of origin. On the part of ex-participants, of the 90 that responded $17(18.9 \%)$ stated that they influenced their posting, while $69(76.7 \%)$ responded in the negative, 4(4.4\%) respondents were indifferent. Of the 91 non-participants who responded to the question on whether they will influence the postings of their children or ward, 37(40.6\%) responded that they will influence their ward's or children's posting. $46(50.5 \%)$ others won't influence the postings, while 8 $(8.8 \%)$ were indifferent. Lastly, gauging the opinion of the prospective participants, the future of the programme, a whopping 63(67\%) noted that they will influence their posting, $17(18.1 \%)$ of them noted that they won't influence their posting, while 14 (14.9\%) were indifferent.

Having established from the preceding table, the level at which participants, current and 
prospective, as well as non-participants influenced and still influence postings to states of service, it is important also to take note of the factors that account for this.

Table 5. Frequency Distribution of Responses on the Factors that necessitate Influencing National Service Posting

\begin{tabular}{l|l|l|l|l|l}
\hline & S & JP & PF & OTHERS & TOTAL \\
\hline CURRENT PARTICIPANTS & 24 & 13 & 12 & 5 & 54 \\
\hline NON-PARTICIPANTS & 35 & 11 & 2 & 4 & 52 \\
\hline PROSPECTIVE PARTICIPANTS & 32 & 30 & 12 & 4 & 78 \\
\hline TOTAL & 91 & 54 & 26 & 13 & 184 \\
\hline
\end{tabular}

\section{S- SECURITY, JP- JOB PLACEMENT, PF- PROXIMITY TO FAMILY, O- OTHERS}

Of all the 184 respondents, 91(49.4\%) of them viewed their security as uppermost reason for influencing National Service postings. 29 (29.3\%) chose job placement as the reason for influencing their posting. Based on the need for proximity to their family members, 26 $(14.1 \%)$ justified the need to influence posting, while $13(7.1 \%)$ respondents had other factors beyond the ones stated. As it may have been observed, security accounts to a large extent for reasons why postings are influenced. To be sure, since the return of democratic governance in 1999, there has been an unprecedented upsurge in the number of violent clashes usually taking religious or ethnic dimensions. The consequences of such clashes are often measured in the loss of lives, of valuable property and the displacement of people.

This has made participants of the programme, both current and prospective, as well as parents and guardians, to be wary of service or releasing their children or wards to serve in such troubled spots. Available data also show that a considerable number of corps members have been caught in the web of the various crises, the degree of involvement however vary from severe injuries to permanent disabilities and in some other cases, death. A few instances of such security breaches that has affected corps members are; the death of Miss Grace Ushagi in Maiduguri, Borno State. She was attacked by assailants on the ground that she was wearing 'khaki trousers' the official uniform of the Youth Corps, she was raped, before she was finally killed. Three corps members, Messrs Ibukun Oluwatosin, Akinjagbin, Tola Odusole and Leke Akande were among the hundreds of people that lost their lives in the 2008 Jos crises. The post 2011 election crises, which engulfed the northern Nigeria, resulting in the death of 10 serving corps members (Iyaji,2012). These instances are indeed fearful enough to scare anyone from serving outside his or her ethnic base; hence the decision to influence postings by participants.

The issue of posting also took centre stage in the Nigerian Senate when Senator Olubunmi Adetunmbi, representing Ekiti North, sponsored a bill to amend the National Youth Service Corps Act. Among other things, the bill sought to give corps members the right to reject postings to states, where crises exist. However, the bill was discarded on the grounds that it is antithetical to the objective of national integration, which the NYSC seems to achieve. Probing further on the issue of Security and National Service, the researcher, sought to know whether or not the participants, particularly the current and prospective participants would 
choose to serve in any part of Nigeria, if their security and job placement was guaranteed.

Table 6. Frequency Distribution of Responses on whether Respondents would serve in any part of the Country, if Security and Job Placement are assured

\begin{tabular}{l|l|l|l|l}
\hline & YES & NO & INDIFFERENT & TOTAL \\
\hline CURRENT PARTICIPANTS & 53 & 16 & 3 & 72 \\
\hline PROSPECTIVE PARTICIPANTS & 56 & 31 & 12 & 99 \\
\hline TOTAL & 109 & 47 & 15 & 171 \\
\hline
\end{tabular}

The table above shows clearly that of the 171 respondents, 109 (63.7\%) are willing and ready to serve in any part of the country, if security and job placements are assured. 47 (27.5\%) will not, and 15 (8.8\%) were indifferent. The former (security) has been discussed earlier, however on the issue of job placement; it is pertinent to note that the dual citizenship status of Nigerian citizens is problematic. As Osaghae (1990) has analytically distinguished, "state" citizenship is that which implies that one is an indigene of a particular state, while "national" citizenship implies citizenship at a higher level, of belonging to Nigeria. The implication of this duality is the possibility of a citizen losing his/her citizenship status in a state, other than his /her state of origin. Thus, as Osoba and Usman (1976) cited in (Osaghae, 1990) note, “... no matter how long a Nigerian has resided in a state of Nigeria of which none of his parents is an indigene, such a Nigerian cannot enjoy the right to participate fully in the public life of that state". Put differently, duration of residency notwithstanding, a non-indigene of a state cannot enjoy the benefits indigenes enjoy among other things, employment in the state institutions (Osaghae 1990:601). It has therefore been a herculean task for non-indigenes to secure jobs in their states of service after they complete their service.

\section{Conclusion}

It has been noted that the need to bring together the disparate groups that make up Nigeria into a harmonious entity is the basis for the implementation of the National Youth Service Corps programme as discussed in this paper. The study revealed among other things that the perception of participants (past, present and prospective) as well as non-participants alike leaves much to be desired. Less than half of the respondents actually see the programme as an instrument of national integration. The greater number sees it either as a job requirement, national obligation, cultural exchange, or community service. The security and general welfare of the participants was also on the front burner. It was observed from the available data that the average Nigerian youth is willing and ready to serve in any part of the country as long as his or her security as well as job placement is assured. Some of the participants complained of the poor remuneration, arguing that it does not reflect the economic reality of the time. Not only is the stipend insufficient, it is sometimes delayed before it is eventually paid. The monthly allowance (which is N19, 800) seems much numerically, but when marched with the rising inflation, is next to nothing for the monthly survival of an average adult citizen in Nigeria. 


\section{Policy Recommendations}

The following policy recommendations are proffered. First that the policy on posting of participants be reviewed. As it stands at present, and as stated in Section 1 (4) (b) of the NYSC Decree, 1993; "that as far as possible, Youths are assigned to jobs in states other than their states of origin," the policy is self-serving as its implementation fails the test of achieving national integration. The recommendation therefore is, rather than posting participants on the basis of State of Origin, the posting should be based on the Participants' ethnic base, so that no participant will be able to serve within his or her ethnic base. The strict implementation of this will no doubt enhance the performance of the programme towards achieving national integration.

The second recommendation will be on the need for governments at all levels to pay more attention to the welfare of corps members. This has become necessary, particularly on account of the data gathered by this study, where many groan of the poor welfare package the programme offers. Among other issues raised as it relates to welfare are; the poor remuneration which sometimes is delayed before payment is made and the inadequacy of accommodation for members. It is commonly held by corps members that they are merely a pool of readily available cheap labour thrown at employers; the remuneration they get is never commensurate to the work done. Thus, it is recommended that the government should consider regular review of the allowances of the participants as the prevailing economic conditions dictate, so that the allowances will reflect the economic reality per time. On the issue of accommodation, at the orientation camps as well as for the duration of the entire programme, the levels of government should see to it that participants are not unhoused or unnecessarily left at the mercy of house-owners who charge exorbitant rates. When the general welfare of participants is well addressed, they will be motivated to serve the nation even more than what is expected. The bunch of ill-motivated participants that are seen around is a clear consequence of their neglected welfare.

The third issue on which this study will make another recommendation bother on security. Perhaps this is the most daunting challenge the programme is currently facing and which has sent fear down the spine of many a participant and parent. The study reveals that security and other related issues come first among issues that need urgent and drastic attention. But for the uncertainty pervading certain parts of the country, participants are willing and ready to serve the nation in any part of the country. Thus, this issue is a serious drawback for the attainment of the objective of national integration. Thus, to stem this tide, it is recommended that as much as possible, the Federal government should bring the general insecurity that currently engulfs the country to its minimum level and ensure as fast as possible that all is done to restore peace to all part of the country.

\section{References}

Adenle, T. (2009). Shedding Southern Nigerians' blood for phantom 'unity' must stop.Retrieved from emotanafrica.com/2011/05/02/shedding-southern-nigerians-blood-forphantom- unity -must -stop/ 
Agbodike, C. (1998). Federal Character Principle and National Integration . In K. Amuwo et al (eds), Federalism and Poltical Restructuring in Nigeria (pp. 177 - 190). Ibadan: Spectrum Books Limited.

Amienyi, O. (2005). Communicating National Integration:Empowering Development in African Countries. Aldershot: Ashgate Publishing Limited.

Ayoade, J. (1998). The Federal Character Principle and the Search for National Integration. In Amuwo,K et al (eds), Federalism and Poltical Restructuring in Nigeria (pp. 101 - 120). Ibadan: Spectrum Books Limited

Ayoade, JAA. (2010). Nigeria:Positive Pessimism and Negative Optimism. Ibadan: Faculty of the Social Sciences, University of Ibadan.

Egunyomi, A. (2017). The National Youth Service Corps: A Bridge to Nationalism in Nigeria. Retrieved from https://www.cfr.org/blog/national-youth-service-corps-bridge-nationalism-nigeria.

Fatile, J., \& Adejuwon, K. (2010). Ethnicity and National Integration in Nigeria:The post Colonial Experience, In Osuntokun, A, Ukaogo,A., Akachi,O (eds). Nigerian StudiesReadings in History, Politics, Society and Culture. New Jersey: Goldmine and Jacob Publishers.

Iyizoba, W. (1982). Nigerian Youth Service Corps: An Evaluation of an Attempt to Foster National Unity in the Face of Ethnic Diversity. The State University of New Jersey, Department of Sociology, Gradute School of Rutgers, New Jersey.Unpublished Ph.D Thesis.

Marenin, O. (1979). National Service and National conscienciousness in Nigeria. Journal of Modern African Studies , 629 - 654. https://doi.org/10.1017/S0022278X00007485

Morrison, D. G., \& Stevenson, H. M. (1971). Political instability in independent black Africa: more dimensions of conflict behavior within nations. Journal of Conflict resolution, 15, 347368. https://doi.org/10.1177/002200277101500306

Obadare, E. (2007). The Effects of National Service in Africa, With a Focus on Nigeria. In A. Sherranden, Civic Service Worldwide: Impacts and Inquiry (pp. 35 - 59). New York: M.E Sharpe.

Obadare, E. (2010). Statism, Youth and Civic Imagination-A critical Study of the National Youth Service Corps Programme in Nigeria. Dakar: CODESRIA.

Odumade, B. (2006). National Youth Service Corps: In search of Relevance. Retrieved from https:/guardian.ng/opinion/national-youth-service-corps-in-search-of-relevance/

Ojo, E. (2009). Federalism and the Search for National Integration in Nigeria. African Journal of Political Science and International Relations , 3(9), 384-395.

Ojo, E. O. (2009). Mechanisms of national integration in a multi-ethnic federal state: the Nigerian experiment. 


\section{Macrothink}

Journal of Public Administration and Governance ISSN 2161-7104 2019, Vol. 9, No. 2

Oni, M., \& Ogundinwin, A. (2010). Four Republics: A Critical Discourse of the Culture of Political Parties, In Osuntokun, A, Ukaogo,A., Akachi,O (eds). Nigerian Studies- Readings in History, Politics,Society and Culture. New Jersey: Goldmine and Jacob Publishers.

Osaghae, E. (1990). The Problem of Citizenship in Nigeria. Istituto Italiano per l'Africa e l'Oriente , 45(4), 593-611.

\section{Copyright Disclaimer}

Copyright for this article is retained by the author(s), with first publication rights granted to the journal.

This is an open-access article distributed under the terms and conditions of the Creative Commons Attribution license (http://creativecommons.org/licenses/by/4.0/). 